TITLE:

\title{
Development of DNA
} Metalloenzymes Using a Rational Design Approach and Application in the Asymmetric Diels-Alder Reaction

\section{$\operatorname{AUTHOR}(\mathrm{S})$ :}

Park, Soyoung; Okamura, Izumi; Sakashita, Sohei; Yum, Ji Hye; Acharya, Chiranjit; Gao, Li; Sugiyama, Hiroshi

\section{CITATION:}

Park, Soyoung ... [et al]. Development of DNA Metalloenzymes Using a Rational Design Approach and Application in the Asymmetric Diels-Alder Reaction. ACS Catalysis 2015, 5(8): 4708-4712

\section{ISSUE DATE:}

2015-08-07

URL:

http://hdl.handle.net/2433/230917

\section{RIGHT:}

(c) 2015 American Chemical Society. This document is the Accepted Manuscript version of a Published Work that appeared in final form in ACS Catalysis, copyright (c) American Chemical Society after peer review and technical editing by the publisher. To access the final edited and published work see 10.1021/acscatal.5b01046. The full-text file will be made open to the public on 07 August 2016 in accordance with publisher's 'Terms and Conditions for Self-Archiving'. This is not the published version. Please cite only the published version. この論文は出版社版でありません。引用の際 には出版社版をご確認ご利用ください。 


\section{Development of DNA Metalloenzymes Using a}

\section{Rational Design Approach and Application in the}

\section{Asymmetric Diels-Alder Reaction}

Soyoung Park, * ${ }^{1}$ Sohei Sakashita, ${ }^{1}$ Izumi Okamura, ${ }^{1}$ Acharya Chiranjit, ${ }^{4}$ Li Gao, ${ }^{,}$and Hiroshi Sugiyama ${ }^{*,{ }^{2},,_{3}}$

Department of Chemistry, Graduate School of Science, Kyoto University, Kitashirakawa-oiwakecho, Sakyo-ku, Kyoto 606-8502, Japan

${ }^{2}$ Institute for Integrated Cell-Material Sciences (iCeMS), Kyoto University, Yoshida-ushinomiyacho, Sakyo-ku, Kyoto 606-8501, Japan

${ }^{3}$ CREST, Japan Science and Technology Corporation (JST), Sanbancho, Chiyoda-ku, Tokyo 102-0075, Japan

${ }^{4}$ Department of Chemistry, CSIR-Indian Institute of Chemical Biology, Raja S. C. Mullick Road, Jadavpur, Kolkata 700-032, India

${ }^{4}$ Department für Chemie, Ludwig-Maximilians-Universität, Butenandtstrasse 5-13, 81377 München, Germany

*Corresponding author: Dr. Soyoung Park, Prof. Dr. Hiroshi Sugiyama

Tel.: (+)81-75-753-4002; Fax: (+)81-75-753-3670

E-mail: oleesy@kuchem.kyoto-u.ac.jp, hs@kuchem.kyoto-u.ac.jp (H.S.)

Received Date: (to be automatically inserted after your manuscript is accepted if required according to the journal that you are submitting your paper to) 


\title{
KEYWORDS
}

DNA, Metalloenzyme, Asymmetric catalysis, Diels-Alder reaction

\begin{abstract}
We report here DNA metalloenzymes that catalyze the asymmetric Diels-Alder reaction with high conversion, excellent endo/exo selectivities, and enantioselectivities up to $-97 \%$ ee. Their catalytic-pocket architectures were organized using a rational design strategy based on the $\mathrm{Cu}(\mathrm{II})$ ion, the composition of nucleobases, and the incorporation of flexible linkers. Without using the mirror image of B-DNA, DNA metalloenzymes afforded the opposite enantiomer of the Diels-Alder product compared with those obtained using a supramolecular $\mathrm{Cu}(\mathrm{II})-\mathrm{dmbpy} / \mathrm{st}-\mathrm{DNA}$ catalyst system. Furthermore, we devised DNA metalloenzymes without the incorporation of an artificial binding ligand and successfully performed a Diels-Alder reaction. This study provides a new perspective on the catalytic repertoire of nucleic acids and will expand the application scope of metalloenzymes.
\end{abstract}

\section{Introduction}

In nature, a variety of metalloenzymes catalyze biologically essential chemical reactions under mild reaction conditions with high efficiency, definitive substrate 
specificity, and excellent enantioselectivity, beyond the performance of synthetic catalysts. Taking inspiration from the superior characteristics of metalloenzymes, the development of artificial metalloenzymes that combine metal-assisted catalysis with a chiral biomacromolecule has received attention as an attractive research concept for developing environmentally friendly and efficient catalysts for the synthesis of enantiomerically pure compounds. ${ }^{1}$ Among the biomolecules that are used as the chiral scaffold, DNA is a notable chiral source because of its many advantageous properties, such as its unique helical chirality and chemical stability, and the diverse three-dimensional structures created by the simple four-letter alphabet. In 2005, Feringa and Roelfes developed the novel concept of DNA-based asymmetric catalysis with a metal complex, DNA, and a binding ligand, and reported Diels-Alder reactions. ${ }^{2}$ Since then, a series of DNA metalloenzymes have been developed and applied successfully to the important carbon-carbon or carbon-heteroatom bond-forming reactions, such as the Michael additions, Friedel-Crafts alkylations, syn-hydrations, and fluorination.,4 Regarding the structural diversity of the DNA, G-quadruplex DNA metalloenzymes have been developed and investigated based on the relationship between the conformation of the quadruplex DNA and the catalytic reaction. ${ }^{5}$ In addition, remarkable approaches have been reported to control the enantiomeric preference of the DNA-based asymmetric catalysis. Roelfes and coworkers reported that the enantioselectivity of the products in the Diels-Alder and Friedel-Crafts alkylation reactions could be controlled by changing the denticity of the ligand coordinated to the $\mathrm{Cu}(\mathrm{II})$ ion. $^{6}$ Smietana and Arseniyadis demonstrated that the left-handed DNA-based catalyst made from L-nucleic acids gave rise to the opposite enantiomeric outcome in the $\mathrm{Cu}$ (II)-catalyzed Friedel-Crafts alkylation and Michael addition reactions compared with the natural right-handed DNA. ${ }^{7}$

Very recently, we devised artificial DNA metalloenzymes with intrastrand bipyridine ligands via direct incorporation into the phosphate backbone, and performed asymmetric intramolecular Friedel-Crafts alkylation to extend our understanding of DNA-based asymmetric catalysis. ${ }^{8}$ In a previous study, we identified the critical factors that affect the reactivity and enantioselectivity of DNA-based asymmetric catalysis, such as the counter base of metal complexes, neighboring bases in the active site, and disposition of the active site. Based on these observations, we established a systematic strategy for the development of DNA metalloenzymes via the rational creation of an 
active site. Herein, we report the development and application of copper-containing DNA metalloenzymes for asymmetric Diels-Alder reactions.

\section{Results and Discussion}

In our previous study, we found that cytosine exhibited distinct features compared with other bases (A, T, and $\mathrm{G}$ ) in the determination of the catalytic capability of the $\mathrm{Cu}$ (II)-bipyridine-DNA conjugate catalyst. For instance, the DNA-based hybrid catalysts produced by the combination of an intrastrand bipyridine ligand and cytosine as a counter base afforded the best result regarding the cyclized product, with a yield of $71 \%$ and enantioselectivity of $84 \%$ ee in intramolecular Friedel-Crafts alkylations. ${ }^{8}$ Therefore, we have focused on cytosine at the active site for the creation of the coordination environment, and designed a DNA metalloenzyme via the direct incorporation of flexible linkers to control the size of the catalytic site. In this regard, we introduced a triethylene glycol linker into the DNA phosphate backbone and generated a variety of $\mathrm{Cu}(\mathrm{II})-\mathrm{DNA}$-triethylene glycol conjugates. ${ }^{9}$

Oligo(ethylene glycol)s are used widely as linkers or spacers because they are inexpensive, water soluble, and commercially available in a broad range of molecular-weight distributions. The phosphoramidites of triethylene glycol linkers were readily synthesized by phosphitylation and incorporated into the DNA oligonucleotides by automated solid-phase synthesis (see SI, Scheme S1). We generated DNA metalloenzymes based on 13-mer DNA oligonucleotides, 5'-d(GCATGXEYACGGT)$3^{\prime} / 5^{\prime}-\mathrm{d}\left(\right.$ ACCGTXCYCATGC)-3', where $\mathbf{E}=$ a triethylene glycol linker. ${ }^{10}$ The asymmetric Diels-Alder reaction between aza-chalcone 1a and cyclopentadiene $\mathbf{2}$ was performed to prove the catalytic activity of $\mathrm{Cu}(\mathrm{II})$-DNA-triethylene glycol conjugates. The results are summarized in Table 1. Under the reaction conditions (20 mM MOPS buffer at $\mathrm{pH} 6.5,3 \mathrm{~mol} \%$ of $\mathrm{Cu}\left(\mathrm{NO}_{3}\right)_{2}$, and $4 \mathrm{~mol} \%$ of DNA), the present $\mathrm{Cu}(\mathrm{II})-\mathrm{DNA}-$ ethylene glycol conjugates afforded the Diels-Alder adduct with significant conversion, endo/exo selectivity, and a promising enantioselectivity (entry 1 in Table 1). We examined the neighboring base pairs of the cytosine and the triethylene glycol linker. As shown in entries 1-6 in Table 1, we found that the enantioselectivities were influenced greatly by the neighboring base pairs of the cytosine and the triethylene 
glycol linker. For example, the DNA metalloenzyme comprising ODN3/ODN12 (CEC-/-GCG-) and the $\mathrm{Cu}(\mathrm{II})$ ion gave the product with $-13 \%$ ee, whereas the DNA metalloenzyme comprising ODN5/ODN14 (-TET-/-ACA-) and the Cu(II) ion had a markedly increased enantioselectivity, up to $-81 \%$ ee.

To our great delight, the DNA metalloenzyme generated by the combination of cytosine and the neighboring base pair -AET- afforded the Diels-Alder adduct with high conversion (99\%) and excellent enantioselectivity ( $-94 \% e e)$, together with very high endo/exo selectivity (entry 6 in Table 1). Subsequently, we replaced the triethylene glycol linker with more hydrophobic alkyl linkers. After considering the alkyl chain length, octyl and propyl linkers, such as ODN7 and ODN8, were introduced into the DNA strand and investigated. As shown in entries 7 and 8, the DNA metalloenzymes that included alkyl linkers also led the completion of Diels-Alder reactions successfully and gave the desired products with high conversions and excellent endo/exo selectivities and enantioselectivities.

When we performed the Diels-Alder reaction using a DNA metalloenzyme with a propyl linker, the corresponding product was obtained up to $-97 \%$ ee. The control experiment using ODN9/ODN15 in the presence of $\mathrm{Cu}(\mathrm{II})$ ions resulted in low selectivities, which suggests that the security of the space via the introduction of ethylene glycol or alkyl linkers is important for affording high enantioselectivity (entry 9 in Table 1). When the reaction was performed using a single DNA-ethylene glycol conjugate strand, ODN6, and $\mathrm{Cu}$ (II) ions, very low enantioselectivity was obtained (see entry 10 in Table 1). The results of this experiment indicate that the double-helical structure of the $\mathrm{Cu}(\mathrm{II})$-DNA-triethylene glycol conjugates is important for inducing enantioselectivity in the asymmetric Diels-Alder reaction.

Table 1. Asymmetric Diels-Alder reaction catalyzed by DNA metalloenzymes containing $\mathrm{Cu}(\mathrm{II})$ and a triethylene glycol (alkyl) linker. 


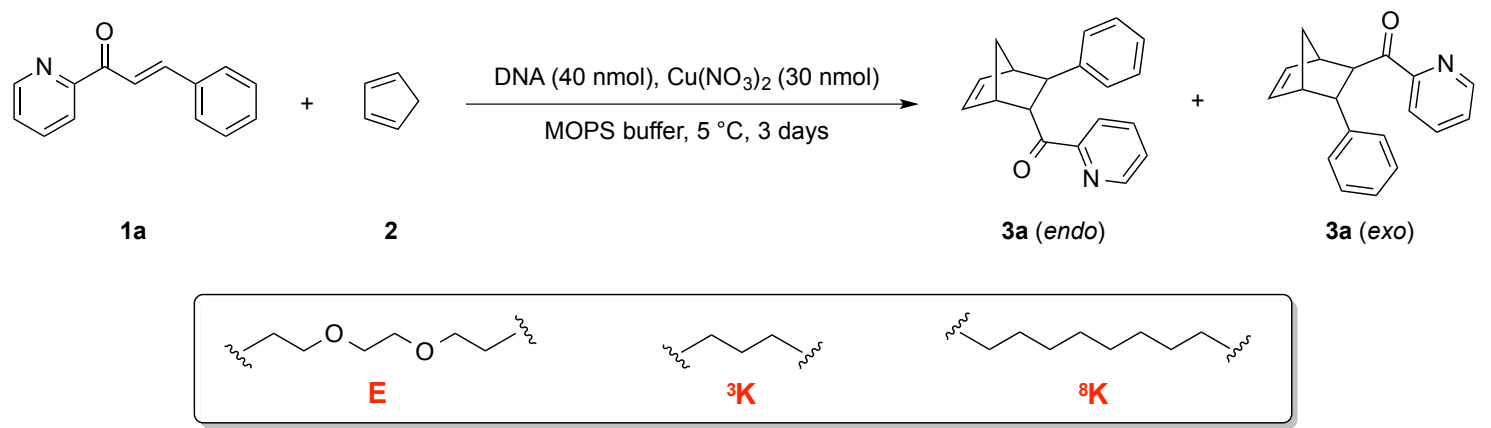

\begin{tabular}{|c|c|c|c|c|}
\hline entry ${ }^{a}$ & DNA sequences & $e e(\%)$ & endolexo & conversion (\%) \\
\hline 1 & $\begin{array}{l}\text { 5'-GCATGGECACGGT-3' (ODN1) } \\
\text { 3'-CGTACCCGTGCCA-5' (ODN10) }\end{array}$ & -36 & $14 / 1$ & 99 \\
\hline 2 & $\begin{array}{l}\text { 5'-GCATGGEGACGGT-3' (ODN2) } \\
\text { 3'-CGTACCCCTGCCA-5' (ODN11) }\end{array}$ & -41 & $10 / 1$ & 57 \\
\hline 3 & $\begin{array}{l}\text { 5'-GCATGCECACGGT-3' (ODN3) } \\
\text { 3'-CGTACGCGTGCCA-5' (ODN12) }\end{array}$ & -13 & $16 / 1$ & 75 \\
\hline 4 & $\begin{array}{l}\text { 5'-GCATGAEAACGGT-3' (ODN4) } \\
\text { 3'-CGTACTCTTGCCA-5' (ODN13) }\end{array}$ & -58 & $22 / 1$ & 70 \\
\hline 5 & $\begin{array}{l}\text { 5'-GCATGTETACGGT-3' (ODN5) } \\
\text { 3'-CGTACACATGCCA-5' (ODN14) }\end{array}$ & -81 & $20 / 1$ & 99 \\
\hline $6^{b}$ & $\begin{array}{l}\text { 5'-GCATGAETACGGT-3' (ODN6) } \\
\text { 3'-CGTACTCATGCCA-5' (ODN15) }\end{array}$ & -94 & $>40 / 1$ & 99 \\
\hline $7^{b}$ & $\begin{array}{l}\text { 5'-GCATGA'KTACGGT-3' (ODN7) } \\
\text { 3'-CGTACTCATGCCA-5' (ODN15) }\end{array}$ & -87 & $36 / 1$ & 95 \\
\hline $8^{b}$ & $\begin{array}{l}\text { 5'-GCATGA3'KTACGGT-3' (ODN8) } \\
\text { 3'-CGTACTCATGCCA-5' (ODN15) }\end{array}$ & -97 & $>40 / 1$ & 98 \\
\hline 9 & $\begin{array}{l}\text { 5'-GCATGAGTACGGT-3' (ODN9) } \\
\text { 3'-CGTACTCATGCCA-5' (ODN15) }\end{array}$ & -13 & $8 / 1$ & 82 \\
\hline 10 & 5'-GCATGAETACGGT-3' (ODN6) & -10 & $5 / 1$ & 87 \\
\hline
\end{tabular}

a Experiments were carried out using $3.3 \mathrm{mM}$ aza-chalcone, $80 \mathrm{mM}$ cyclopentadiene, $0.13 \mathrm{mM}$ DNA, and $0.1 \mathrm{mM} \mathrm{Cu}\left(\mathrm{NO}_{3}\right)_{2}$ at $5{ }^{\circ} \mathrm{C}$ in $20 \mathrm{mM}$ MOPS buffer $(\mathrm{pH} 6.5)$ for 3 days. The yields and enantioselectivities were determined by chiral HPLC analysis. ${ }^{\mathrm{b}}$ Results represent the average value of more than two experiments. The enantioselectivities were reproducible within $\pm 5 \%$. The yields were reproducible within $\pm 10 \%$.

Interestingly, we found that the present DNA metalloenzyme afforded the opposite enantiomeric outcome compared with the previously reported $\mathrm{Cu}(\mathrm{II})-\mathrm{dmbpy} / \mathrm{st}-\mathrm{DNA}$ 
catalytic system. In addition, the circular dichroism spectra of the DNA duplex formed by ODN6/ODN15 or ODN8/ODN15 in the presence of the $\mathrm{Cu}$ (II) complex indicated a typical right-handed B-DNA structure (see SI). This result clearly demonstrates that the enantiomeric preference of the reaction could be changed readily via the introduction of simple linear linkers, such as an ethylene glycol linker and an alkyl chain linker, to the DNA phosphate backbone; i.e., the enantioselectivity could be reversed completely by perturbing only the catalytic site in the DNA duplex, without an overall change in the helical chirality of the duplex.

To confirm the catalytic ability of the present DNA metalloenzymes for asymmetric Diels-Alder reactions, the scope of dienophiles with various functional groups was investigated under optimized reaction conditions (Table 2). Using a $\mathrm{Cu}(\mathrm{II})-\mathrm{DNA}-$ triethylene glycol conjugate, dienophiles containing the substituted phenyl group with electron-withdrawing or -donating substituents gave the corresponding product in almost full conversion with high enantioselectivity (entries 1-3 in Table 2). In the case of a dienophile including a $p$-nitro group on the phenyl ring, a $\mathrm{Cu}$ (II)-DNA-propyl linker conjugate was used for the reaction to avoid the electrostatic repulsion between the nitro group and the triethylene glycol linker. ${ }^{11}$ In place of 2-acyl pyridyl, the use of the 2-acyl imidazole group also led to high product enantioselectivity ( $-88 \%$ ee, entry 5 in Table 2).

Table 2. Substrate scope of the asymmetric Diels-Alder reaction by DNA metalloenzymes. 
<smiles>[R]C=CC([R])=O</smiles>

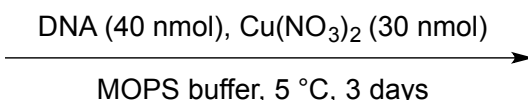

2

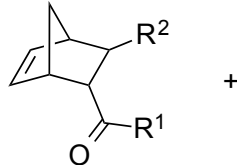

3b-f (endo)

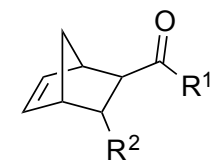

3b-f (exo)

1b: $\mathrm{R}^{1}=2$-pyridyl, $\mathrm{R}^{2}=p-\mathrm{MeOC}_{6} \mathrm{H}_{4}$

1c: $\mathrm{R}^{1}=2$-pyridyl, $\mathrm{R}^{2}=0-\mathrm{ClC}_{6} \mathrm{H}_{4}$

1d: $\mathrm{R}^{1}=2$-pyridyl, $\mathrm{R}^{2}=p-\mathrm{BrC}_{6} \mathrm{H}_{4}$

1e: $\mathrm{R}^{1}=2$-pyridyl, $\mathrm{R}^{2}=p-\mathrm{NO}_{2} \mathrm{C}_{6} \mathrm{H}_{4}$

1f: $\mathrm{R}^{1}=2-\left(1-\right.$ methylimidazolyl), $\mathrm{R}^{2}=\mathrm{C}_{6} \mathrm{H}_{5}$

\begin{tabular}{ccccc}
\hline entry $^{a}$ & substrate & ee $(\%)^{\mathrm{b}}$ & endo/exo & conversion (\%) \\
\hline 1 & 1b & -92 & $>40 / 1$ & 99 \\
2 & 1c & -97 & $>40 / 1$ & 99 \\
3 & 1d & -86 & $25 / 1$ & 99 \\
$4^{b}$ & 1e & -96 & $>40 / 1$ & 99 \\
5 & 1f & -88 & $21 / 1$ & 99 \\
\hline
\end{tabular}

a Experiments were carried out using $3.3 \mathrm{mM}$ aza-chalcone, $80 \mathrm{mM}$ cyclopentadiene, $0.13 \mathrm{mM}$ DNA (ODN6/ODN15), and $0.1 \mathrm{mM} \mathrm{Cu}\left(\mathrm{NO}_{3}\right)_{2}$ at $5{ }^{\circ} \mathrm{C}$ in $20 \mathrm{mM}$ MOPS buffer ( $\mathrm{pH}$ 6.5) for 3 days. The yields and enantioselectivities were determined by chiral HPLC analysis. ${ }^{\mathrm{b}}$ ODN8/ODN15 was used in this experiment.

The results observed here clearly indicate that DNA metalloenzymes could perform the asymmetric Diels-Alder reaction successfully, even if they had no binding ligand for $\mathrm{Cu}$ (II) ions, such as bipyridine or phenanthroline. This suggests that we might be able to create an enzyme-like 'active site' on the DNA duplex that could afford high enantioselectivity without the introduction of a binding ligand or linker moiety. Therefore, we devised DNA metalloenzymes comprising three oligonucleotides and $\mathrm{Cu}$ (II) ions. To generate ample space for the active site, we excluded the counter base for cytosine. The template oligonucleotide strand (15-mer) with cytosine in the center was hybridized with two kinds of complementary oligonucleotides (7-mers) in the presence of $\mathrm{Cu}$ (II) ions, and gave rise to DNA metalloenzymes. The catalytic ability of these DNA metalloenzymes was investigated in the asymmetric Diels-Alder reaction. Surprisingly, as shown in Table 3, the designed DNA metalloenzymes afforded the Diels-Alder adducts in almost full conversion with very high enantioselectivities. 
Regarding the neighboring base pairs of the cytosine, similar to $\mathrm{Cu}(\mathrm{II})$-DNA-ethylene glycol (alkyl linker) conjugates, a neighboring A-T pair gave higher enantioselectivity ( $-64 \%$ ee, entry 1 in Table 3$)$ than did a $\mathrm{C}-\mathrm{G}$ pair $(-17 \%$ ee, entry 2 in Table 3$)$ in the present reaction. Furthermore, considering the proximity to cytosine, the presence of a $3^{\prime}$ - or $5^{\prime}$-end phosphate group on the short complementary oligonucleotides increased the enantioselectivity of the Diels-Alder product. As shown in entry 5 in Table 3, a DNA metalloenzyme containing 5 '- and 3 '-end phosphorylated complementary oligonucleotides afforded the Diels-Alder product with $-83 \%$ ee.

$\mathrm{Li}$ and colleagues reported enantioselective Friedel-Crafts alkylations using a human telomeric G4DNA metalloenzyme that was assembled using G4DNA and $\mathrm{Cu}(\mathrm{II})$ ions without additional ligands (up to $75 \%$ ee). ${ }^{5 \mathrm{c}}$ In this study, we demonstrated clearly that DNA metalloenzymes comprising a native DNA duplex and Cu(II) ions without any artificial binding ligand can function as the asymmetric catalyst for the Diels-Alder reaction to give almost full conversion, high enantioselectivity, and an excellent endo/exo ratio.

Table 3. Investigation of DNA metalloenzymes for the asymmetric Diels-Alder reaction. 


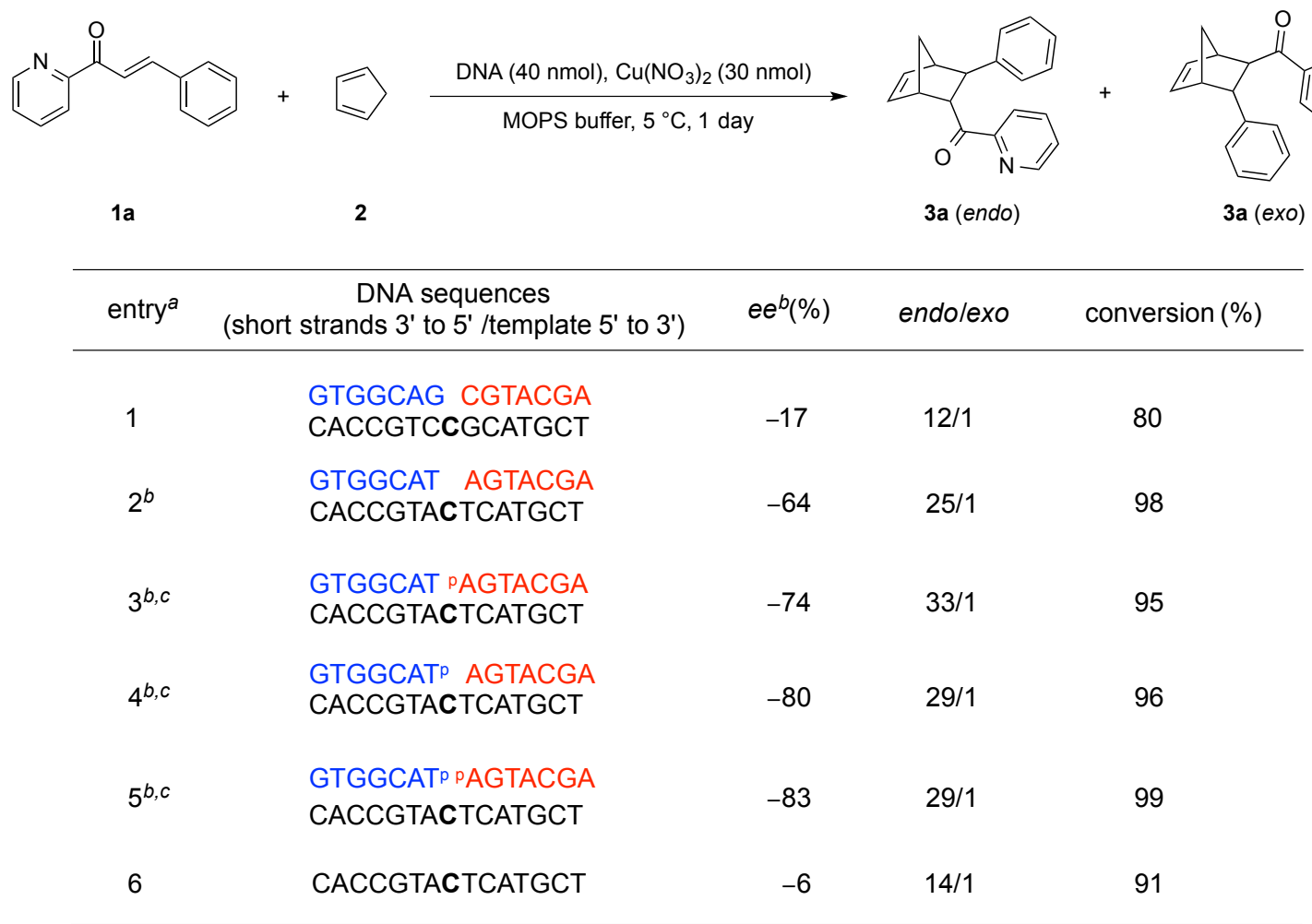

a Experiments were carried out using $3.3 \mathrm{mM}$ aza-chalcone, $80 \mathrm{mM}$ cyclopentadiene, $0.13 \mathrm{mM}$ DNA, and $0.1 \mathrm{mM} \mathrm{Cu}\left(\mathrm{NO}_{3}\right)_{2}$ at $5{ }^{\circ} \mathrm{C}$ in $20 \mathrm{mM}$ MOPS buffer $(\mathrm{pH}$ 6.5) for 1 day. The yields and enantioselectivities were determined by chiral HPLC analysis. ${ }^{b}$ Results represent the average value of more than two experiments. The enantioselectivities were reproducible within $\pm 5 \%$. The yields were reproducible within $\pm 10 \%$. ${ }^{\mathrm{c}}$ The $\mathrm{T}^{\mathrm{p}}$ means that the $\mathrm{T}$ at the $5^{\prime}$ position contains a phosphate group. The ${ }^{\mathrm{p}} \mathrm{A}$ means that the $\mathrm{A}$ at the $3^{\prime}$ position contains a phosphate group.

DNA double-helix structures that represent the conformation of the active site for the substrates could be suggested by a molecular modeling study using an Amber force field. Based on the DNA metalloenzymes that provided outstanding results, such as the oligonucleotides with the sequence $55^{\prime}-\mathrm{d}\left(\right.$ GCATGAETACGGT) $-3^{\prime} / 5^{\prime}-$ d(ACCGTACTCATGC)-3' (ODN6/ODN15), plausible models of the DNA metalloenzyme were constructed (Figure 1). Although the exact location of the $\mathrm{Cu}(\mathrm{II})$ ion is unclear, the results obtained suggest that the combination of cytosine and copper plays an important role in the creation of the catalytic pocket to induce high enantioselectivity in the Diels-Alder reaction. ${ }^{12}$ Considering the correlation between enantioselectivity and the structure of DNA metalloenzymes, the presence of triethylene 
glycol (alkyl) linkers or phosphate groups on the complementary strand corresponding to the template strand containing cytosine might provide the steric conformation that will control the enantioselectivity of the product. Further studies are under way to explore the present DNA metalloenzymes in greater detail.

(a)

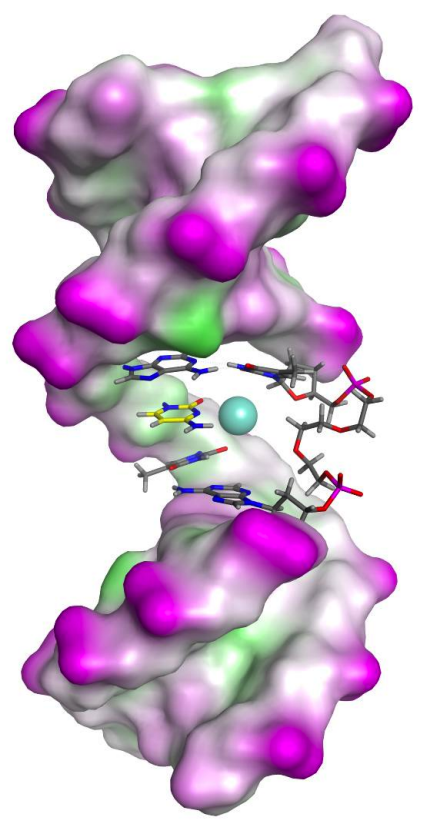

(c)

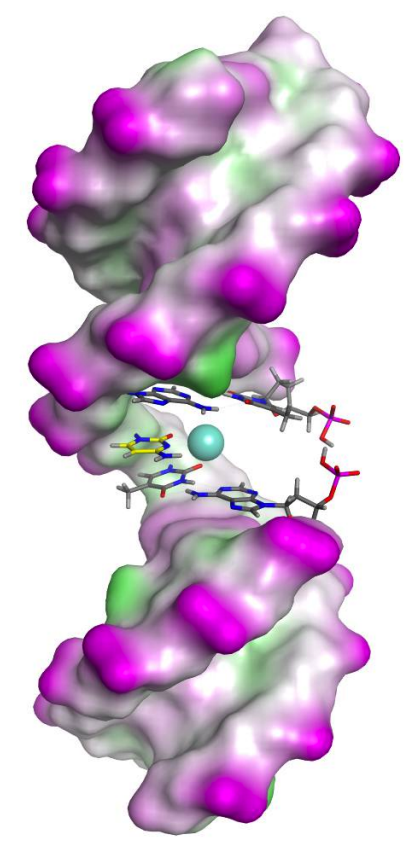

(b)

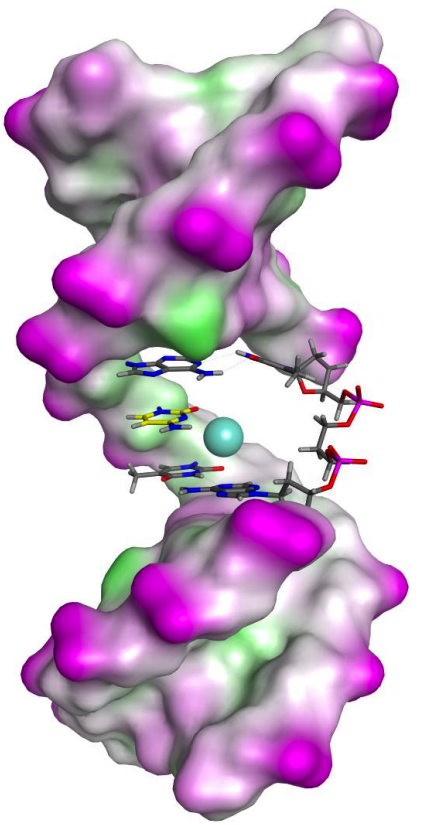

(d)

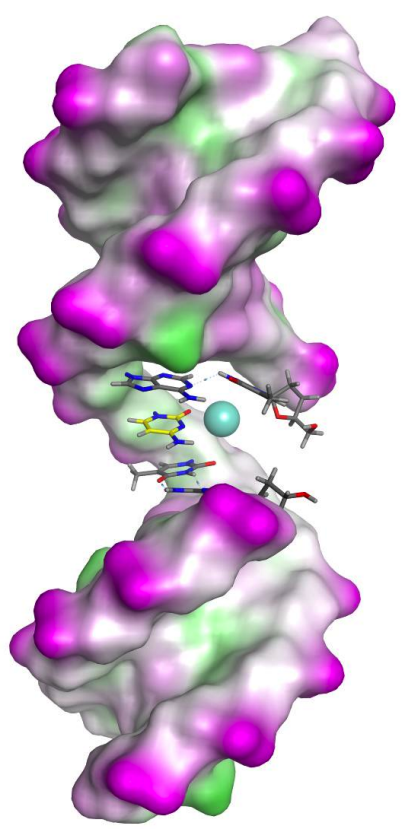


Figure 1. Plausible molecular models of DNA metalloenzymes by energy minimization using the Amber force field. DNA metalloenzymes based on a) ODN6/ODN15 (entry 6 in Table 1), b) ODN8/ODN15 (entry 8 in Table 1), c) 3'-GTGGCAT-5', 3'AGTACGA-5'/5'-CACCGTACTCATGCT-3' (entry 2 in Table 3), d) 3'-GTGGCAT ${ }^{p}$ $-5^{\prime}, 3^{\prime}-{ }^{\mathrm{p}}$ AGTACGA-5'/5'-CACCGTACTCATGCT-3' (entry 5 in Table 3). The color of the molecular surface represents the lipophilicity (pink, hydrophilic; white, neutral; light green, lipophilic).

\section{Conclusion}

In conclusion, we developed copper-containing DNA metalloenzymes via the direct introduction of flexible linkers, and successfully applied them in the asymmetric Diels-Alder reaction. We established a systematic strategy for the development of ligand-free DNA metalloenzymes via the construction of an active site. The devised DNA metalloenzymes afforded an unexpected reverse enantioselectivity for the asymmetric Diels-Alder reaction compared with the $\mathrm{Cu}(\mathrm{II})-\mathrm{dmbpy} / \mathrm{st}-\mathrm{DNA}$ system reported previously. These results strongly support the potential of our rational design approach for the creation of an active site in the DNA duplex. Further investigations of the application of DNA metalloenzymes are currently ongoing in our laboratory.

\section{ASSOCIATED CONTENT}

Supporting Information

Synthetic routes of triethylene glycol and alkyl linkers, characterization data of new compounds, HPLC data, ESI-TOF-Mass data and CD spectra of oligonucleotides. This material is available on the WWW under http://dx.doi.org/xx/xxxx/anie.xxxxx 


\section{ACKNOWLEDGMENT}

We express our sincere thanks for the CREST grant from the Japan Science and Technology Corporation (JST), grants from the WPI program (iCeMS, Kyoto University), and for the global COE program from the Ministry of Education, Culture, Sports, Science and Technology (MEXT), Japan.

\section{REFERENCES}

[1] For reviews, see: a) B. G. Davis, Curr. Opin. Biotechnol. 2003, 14, 379-386; b) C. M. Thomas, T. R. Ward, Chem. Soc. Rev. 2005, 34, 337-346; c) R. Krämer, Angew. Chem. Int. Ed. 2006, 45, 858-860; d) Y. Lu, Angew. Chem. Int. Ed. 2006, 45, 55885601; e) C. Letondor, T. R. Ward, ChemBioChem 2006, 7, 1845-1852; f) M. D. Mihovilovic, J. Chem. Technol. Biotechnol. 2007, 82, 1067-1071.

[2] G. Roelfes, B. L. Feringa. Angew. Chem. Int. Ed. 2005, 44, 3230-3232. 
[3] For reviews, see: a) G. Roelfes. Mol. BioSyst. 2007, 3, 126-135; b) A. J. Boersma, R. P. Megens, B. L. Feringa, G. Roelfes. Chem. Soc. Rev, 2010, 39, 2083-2092; c) S. K. Silverman. Angew. Chem. Int. Ed. 2010, 49, 7180-7201; d) S. Park, H. Sugiyama. Angew. Chem. Int. Ed. 2010, 49, 3870-3878; e) S. Park, H. Sugiyama. Molecules $2012,17,12792-12803$.

[4] a) D. Coquière, B. L. Feringa, G. Roelfes. Angew. Chem. Int. Ed. 2007, 46, 93089311; b) A. J. Boersma, B. L. Feringa, G. Roelfes. Org. Lett. 2007, 9, 3647-3650; c) N. Shibata, H. Yasui, S. Nakamura, T. Toru. T. Syn. Lett. 2007, 1153-1157; d) A. J. Boersma, B. L. Feringa, G. Roelfes. Angew. Chem. Int. Ed. 2009, 48, 3346-3348; e) P. Fournier, R. Fiammengo, A. Jäschke, Angew. Chem. Int. Ed. 2009, 48, 4426-4429; f) A. J. Boersma, D. Coquière, D. Greerdink, F. Rosati, B. L. Feringa, G. Roelfes. Nature Chem. 2010, 2, 991-995; g) S. Park, K. Ikehata, R. Watabe, Y. Hidaka, A. Rajendran, H. Sugiyama. Chem. Commun. 2012, 48, 10398-10400. h) J. Oelerich, G. Roelfes. Chem. Sci. 2013, 4, 2013-2017; i) S. Park, K. Ikehata, H. Sugiyama. Biomaterials Science 2013, 1, 1034-1036; j) G. P. Petrova, Z. Ke, S. Park, H. Sugiyama, K. Morokuma. Chem. Phys. Lett. 2014, 600, 87-95; k) E. Benedetti, N. Duchemin, L. Bethge, S. Vonhoff, A. Klussmann, J.-J. Vasseur, J. Cossy, M. Smietana, S. Arsenuyadis. Chem. Commun. 2015, 10.1039/C4CC10190A.

[5] a) S. Roe, D. J. Ritson, T. Garner, M. Searle, J. E. Moses. Chem. Commun. 2010, 46, 4309-4311; b) C. Wang, Y. Li, G. Jia, Y. Liu, S. Lu, C. Li. Chem. Commun. 2012, 48, 6232-6234; c) C. Wang, G. Jia, J. Zhou, Y. Li, Y. Liu, S. Lu, C. Li. Angew. Chem. 
Int. Ed. 2012, 51, 9352-9355; d) M. Wilking, U. Hennecke. Org. Biomol. Chem. 2013, 11, 6940-6945.

[6] A. J. Boersma, B. de Bruin, B. L. Feringa, G. Roelfes. Chem. Commun. 2012, 48, 2394-2396.

[7] J. Wang, E. Benedetti, L. Bethge, S. Vonhoff, A. Klussmann, J.-J. Vasseur, J. Cossy, M. Smietana, S. Arsenuyadis. Angew. Chem. Int. Ed. 2013, 52, 11546-11549.

[8] S. Park, L. Zheng, S. Kumakiri, S. Sakashita, H. Otomo, K. Ikehata, H. Sugiyama. ACS Catalysis 2014, 4, 4070-4073.

[9] a) U. Jakobsen, K. Rohr, S. Vogel. Nucleosides, Nucleotides, and Nucleic Acids, 2007, 26, 1419-1422; b) N. S. Oltra, G. Roelfes. Chem. Commun. 2008, 6039-6041; c) L. Gjonaj, G. Roelfes. ChemCatChem, 2013, 5, 1718-1721.

[10] Complementary strands of ODN6 containing natural bases (A, T, and G) were also examined to investigate the counter base effect. The DNA metalloenzymes by the combination of triethylene glycol and a counter base A, T, or G afforded lower enantioselectivities of product compared with a counter base $C$ (entries 1-3 in Table S2).

[11] In the case of dienophile including a p-nitro group on the phenyl ring, a decrease in enantioselectivity was observed using a $\mathrm{Cu}(\mathrm{II})$-DNA-triethylene glycol conjugate $(99 \%$ conversion, endo/exo $=18 / 1,-59 \%$ ee).

[12] a) K.-H. Cho, S.-W. Joo. Bull. Korean Chem. Soc. 2008, 29, 69-75; b) D. Krilov, V, Gomzi, J. N. Herak Spectrochimica Acta Part A. 2008, 70, 1238-1242. 
Supporting Information

\section{Development of DNA-based Metalloenzymes Using a}

\section{Rational Design Approach and Application in the}

\section{Asymmetric Diels-Alder Reaction}

Soyoung Park, ${ }^{*}{ }^{1}$ Sohei Sakashita, ${ }^{1}$ Izumi Okamura, ${ }^{1}$ Acharya Chiranjit, ${ }^{,}$Li Gao, ${ }^{\text {and }}$ Hiroshi Sugiyama*,2,3

Department of Chemistry, Graduate School of Science, Kyoto University, Kitashirakawa-oiwakecho, Sakyo-ku, Kyoto 606-8502, Japan

${ }^{2}$ Institute for Integrated Cell-Material Sciences (iCeMS), Kyoto University, Yoshida-ushinomiyacho, Sakyo-ku, Kyoto 606-8501, Japan

CREST, Japan Science and Technology Corporation (JST), Sanbancho, Chiyoda-ku, Tokyo 102-0075, Japan

'Department of Chemistry, CSIR-Indian Institute of Chemical Biology, Raja S. C. Mullick Road, Jadavpur, Kolkata 700-032, India

'Department für Chemie, Ludwig-Maximilians-Universität, Butenandtstrasse 5-13, 81377 München, Germany

${ }^{*}$ Corresponding author: Dr. Soyoung Park, Prof. Dr. Hiroshi Sugiyama Tel.: (+)81-75-753-4002; Fax: (+)81-75-753-3670

E-mail: oleesy@kuchem.kyoto-u.ac.jp, hs@kuchem.kyoto-u.ac.jp (H.S.)

\section{Materials}


4,4'-Dimethoxytrityl chloride, triethylamine and 2-cyanoethyl $N, N$-diisopropylchloro phosphoramidite were received from Wako Chemicals and used without further purification. Trimethylene glycol and $N, N$-diisopropylethylamine was purchased from Nacalai and used as received. Diethylene glycol and triethylene glycol was purchased from Aldrich and used as received. Tetraethylene glycol and 1,8-octanediol was purchased from TCI and used as received. All other chemicals and solvents were purchased from Sigma-Aldrich Chemicals Co., Wako Pure Chemical Ind. Ltd., TCI, or Kanto Chemical Co. Inc. and used without further purification and synthetic oligonucleotides were obtained from Sigma Genosys. Water was deionized (specific resistance of $\geq 18.0 \mathrm{MW} \mathrm{cm}$ at $25^{\circ} \mathrm{C}$ ) by a Milli-Q system (Millipore Corp.).

\section{Methods}

NMR spectra were obtained on a JEOL JNM ECA-600 spectrometer operating at 600 $\mathrm{MHz}$ for ${ }^{1} \mathrm{H}$ NMR and $150 \mathrm{MHz}$ for ${ }^{13} \mathrm{C}$ NMR in $\mathrm{CDCl}_{3}$ unless otherwise noted. Flash column chromatography was performed employing Silica Gel 60 (70-230 mesh, Merck Chemicals). Silica-gel preparative thin-layer chromatography (PTLC) was performed using plates from Silica gel $70 \mathrm{PF}_{254}$ (Wako Pure Chemical Ind. Ltd.). Enantiomeric excess (ee) determinations were performed by HPLC analysis (Chiralcel OD-H) using UV-detection. DNA concentrations were measured by Nanodrop ND-1000 spectrophotometer. Rotary mixing of reaction suspension was performed by Intelli-Mixer RM-2 (Elmi).

\section{Synthetic routes for triethylene glycol linkers}




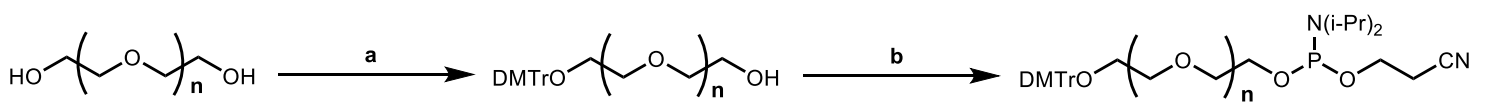

Scheme S1. Reagents and conditions: (a) 0.5 equiv of $\mathrm{DMTrCl}, 0.7$ equiv of $\mathrm{Et}_{3} \mathrm{~N}$, catalytic amount of DMAP, $\mathrm{CH}_{2} \mathrm{Cl}_{2}, \mathrm{rt}, 6 \mathrm{~h}, 32 \%$ yield $(\mathrm{n}=2)$; (b) 2.0 equiv of $N, N$-diisopropylchlorophosphoramidite 3.0 equiv of $i \operatorname{Pr}_{2} \mathrm{NEt}, \mathrm{DCM}, \mathrm{rt}, 1 \mathrm{~h}$. This product was used in the subsequent step without further purification.

E linker

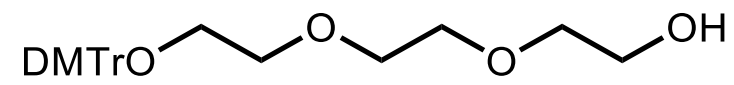

2-(2-(2-(bis(4-methoxyphenyl)(phenyl)methoxy)ethoxy)ethoxy)ethan-1-ol(2)

To a triethylene glycol (3.0 g, $20 \mathrm{mmol})$, which was azeotoropically distilled with 20 $\mathrm{ml}$ of toluene, in dichloromethane $(20 \mathrm{~mL}), \mathrm{Et}_{3} \mathrm{~N}(2.0 \mathrm{ml}, 14 \mathrm{mmol})$, and $\mathrm{N}, \mathrm{N}$-dimethyl-4-aminopyridine $(24.4 \mathrm{mg}, 0.20 \mathrm{mmol})$ was slowly added dimethoxytrityl chloride $(3.39 \mathrm{~g}, 10 \mathrm{mmol})$ in dichloromethane $(15 \mathrm{~mL})$ by dropping funnel over 2 hours and the resulting mixture was stirred for 6 hours at RT. The mixture was evaporated and purified by column chromatography with EtOAc:Hexane $=1: 1$ to afford a yellow oil (1.65 g, 18\% yield). ${ }^{1} \mathrm{H}$ NMR $\left(\mathrm{CDCl}_{3}\right): \delta 7.46\left(\mathrm{~d},{ }^{3} J_{\mathrm{HH}}=8.1 \mathrm{~Hz}, 2 \mathrm{H}\right), 7.35$ $\left(\mathrm{d},{ }^{3} J_{\mathrm{HH}}=8.9 \mathrm{~Hz}, 4 \mathrm{H}\right), 7.28\left(\mathrm{t},{ }^{3} J_{\mathrm{HH}}=7.8 \mathrm{~Hz}, 2 \mathrm{H}\right), 7.20\left(\mathrm{t},{ }^{3} J_{\mathrm{HH}}=7.1 \mathrm{~Hz}, 1 \mathrm{H}\right), 6.82(\mathrm{~d}$, $\left.{ }^{3} J_{\mathrm{HH}}=8.9 \mathrm{~Hz}, 4 \mathrm{H}\right), 3.79(\mathrm{~s}, 6 \mathrm{H}), 3.72(\mathrm{br}, 2 \mathrm{H}), 3.70(\mathrm{~s}, 4 \mathrm{H}) 3.67\left(\mathrm{t},{ }^{3} J_{\mathrm{HH}}=5.1 \mathrm{~Hz}, 2 \mathrm{H}\right)$, $3.63\left(\mathrm{t},{ }^{3} J_{\mathrm{HH}}=4.4 \mathrm{~Hz}, 2 \mathrm{H}\right), 3.25\left(\mathrm{t},{ }^{3} J_{\mathrm{HH}}=5.4 \mathrm{~Hz}, 2 \mathrm{H}\right),{ }^{13} \mathrm{C} \mathrm{NMR}\left(\mathrm{CDCl}_{3}\right): \mathrm{d} 158.39$, $145.03,136.28,130.05,128.19,127.74,126.66,113.03,85.98,72.48,70.81,70.77$, $70.57,63.09,61.85,55.19$. HRMS (ESI-TOF) calculated for $\mathrm{C}_{27} \mathrm{H}_{32} \mathrm{NaO}_{6}[\mathrm{M}+\mathrm{Na}]^{+}$ 475.2097, found 475.2091.

\section{Synthetic routes for alkyl linkers}

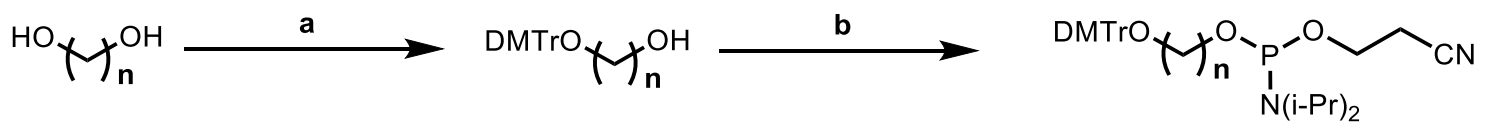

Scheme S2. Reagents and conditions: (a) 0.5 equiv of $\mathrm{DMTrCl}, 0.7$ equiv of $\mathrm{Et}_{3} \mathrm{~N}$, catalytic amount of DMAP, $\mathrm{CH}_{2} \mathrm{Cl}_{2}$, rt, for a day, $76 \%$ yield $(\mathrm{n}=3), 40 \%$ yield $(\mathrm{n}=8)$; (b) 2.0 equiv of $N, N$-diisopropylchlorophosphoramidite 3.0 equiv of $i \operatorname{Pr}_{2} \mathrm{NEt}, \mathrm{DCM}, \mathrm{rt}, 1 \mathrm{~h}$. This product was used in the subsequent step without further purification. 


\section{DMTrO $ح \mathrm{OH}$}

3-(bis(4-methoxyphenyl)(phenyl)methoxy)propan-1-ol(4)

To a trimethyleneglycol $(0.73 \mathrm{~mL}, 10 \mathrm{mmol})$ in dichloromethane (dehydrated, $10 \mathrm{~mL}$ ), $\mathrm{Et}_{3} \mathrm{~N}(0.97 \mathrm{~mL}, 7.0 \mathrm{mmol})$ and N,N-dimethyl-4-aminopyridine (12.3 $\left.\mathrm{mg}, 0.10 \mathrm{mmol}\right)$ was slowly added dimethoxytrityl chloride $(1.70 \mathrm{~g}, 5.0 \mathrm{mmol})$ in dichloromethane (dehydrated, $7.5 \mathrm{~mL}$ ) by dropping funnel and the resulting mixture was stirred for 19 hours at the room temperature. The mixture was evaporated and purified by column chromatography with EtOAc:hexane $=1: 1$ to afford a yellow oil. (1.44 g, $76 \%$ yield $)$ ${ }^{13} \mathrm{C}$ NMR $\left(\mathrm{CDCl}_{3}\right)$ : d 158.62, 145.06, 136.32, 130.13, 128.24, 128.00, 126.92, 113.29, 86.63, 62.57, 62.12, 55.36, 32.59. HRMS (ESI-TOF) calculated for $\mathrm{C}_{24} \mathrm{H}_{26} \mathrm{NaO}_{4}$ $[\mathrm{M}+\mathrm{Na}]^{+} 401.1723$, found 401.1714 .

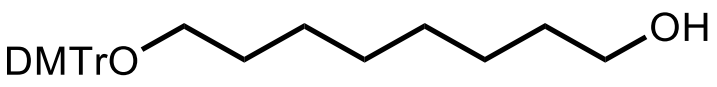

8-(bis(4-methoxyphenyl)(phenyl)methoxy)octan-1-ol(5)

${ }^{1} \mathrm{H}$ NMR $\left(\mathrm{CDCl}_{3}\right): \delta 7.44\left(\mathrm{~d},{ }^{3} \mathrm{~J}_{\mathrm{HH}}=8.9 \mathrm{~Hz}, 2 \mathrm{H}\right), 7.32\left(\mathrm{~d},{ }^{3} \mathrm{~J}_{\mathrm{HH}}=8.8 \mathrm{~Hz}, 4 \mathrm{H}\right), 7.27(\mathrm{t}$, $\left.{ }^{3} \mathrm{~J}_{\mathrm{HH}}=8.1 \mathrm{~Hz}, 2 \mathrm{H}\right), 7.19\left(\mathrm{t},{ }^{3} \mathrm{~J}_{\mathrm{HH}}=7.5 \mathrm{~Hz}, 1 \mathrm{H}\right), 6.82\left(\mathrm{~d},{ }^{3} \mathrm{~J}_{\mathrm{HH}}=8.8 \mathrm{~Hz}, 4 \mathrm{H}\right), 3.79(\mathrm{~s}, 6 \mathrm{H})$, $3.63\left(\mathrm{q},{ }^{3} \mathrm{~J}_{\mathrm{HH}}=6.3 \mathrm{~Hz}, 2 \mathrm{H}\right), 3.01\left(\mathrm{t},{ }^{3} \mathrm{~J}_{\mathrm{HH}}=6.5 \mathrm{~Hz}, 2 \mathrm{H}\right), 1.60$ (quin, ${ }^{3} \mathrm{~J}_{\mathrm{HH}}=7.0 \mathrm{~Hz}, 2 \mathrm{H}$ ), $1.55(\mathrm{~m}, 2 \mathrm{H}), 1.31(\mathrm{~m}, 8 \mathrm{H}), 1.20\left(\mathrm{t},{ }^{3} \mathrm{~J}_{\mathrm{HH}}=5.4 \mathrm{~Hz}, 1 \mathrm{H}\right) .{ }^{13} \mathrm{C} \mathrm{NMR}\left(\mathrm{CDCl}_{3}\right): \mathrm{d} 158.45$, $145.63,136.95,130.18,128.36,127.81,126.68,113.11,85.79,63.59$, 63.22, 55.35, $32.93,30.20,29.59,29.48,26.37,25.83$. HRMS (ESI-TOF) calculated for $\mathrm{C}_{29} \mathrm{H}_{36} \mathrm{NaO}_{4}$ $[\mathrm{M}+\mathrm{Na}]^{+}$471.2506, found 471.2497.

\section{Preparation of phosphoramidite 1 5}

DMT-protected linker derivative ( 0.5 mmol 1.0 equiv) was dissolved in $5 \mathrm{~mL}$ of dry dichloromethane. $N, N$-diisopropylethylamine (1.5 mmol, 3.0 equiv) and 2-cyanoethyl $N, N$-diisopropylchlorophosphoramidite (1.0 mmol, 2.0 equiv) were successively added to the solution at RT, and the reaction mixture was stirred $1 \mathrm{~h}$ at RT. All volatiles were then evaporated and without further purification the residue dissolved in MeCN (1.5 $\mathrm{mL}$ ) for DNA solid synthesis.

\section{Oligonucleotide Synthesis}


ODNs were synthesized on solid supports using triethylene glycol or propyl (octyl) linker-derived phosphoramidites and commercially available $O^{5}$-dimethoxytrityl -2'-deoxyribonucleoside $O^{3}$-phosphoramidites. Solid-phase oligonucleotide synthesis was performed on an ABI DNA synthesizer (Applied Biosystem, Foster City, CA). The modified phosphoramidite was chemically synthesized as described above and without purification incorporated into oligonucleotide through coupling reaction for 10 minutes. Coupling yields linker-derived phosphoramidites were equal to the ones obtained with standard phosphoramidite building blocks. Cleavage from the solid support and deprotection were accomplished with 50:50 of $\mathrm{MeNH}_{2}$ in 40 wt. \% in water and $\mathrm{NH}_{3}$ in 28 wt. $\%$ in water at $\mathrm{rt}$ for $15 \mathrm{~min}$ and then at $65{ }^{\circ} \mathrm{C}$ for $15 \mathrm{~min}$. After purification by HPLC, products were confirmed by ESI-TOFMS (Table S2). DNA concentrations were determined by using the Nano drop ND-1000 (Nano-drop Technologies, Wilmington, DE).

Table S1. ESI-TOF-Mass data of ODNs.

\begin{tabular}{ccc}
\hline DNA oligomer & Calcd. & Found \\
\hline 5'-GCATGGECACGGT-3' (ODN1) & 3898.6 & 3899.4 \\
5'-GCATGGEGACGGT-3' (ODN2) & 3938.6 & 3938.4 \\
5'-GCATGCECACGGT-3' (ODN3) & 3858.6 & 3858.1 \\
5'-GCATGAEAACGGT-3' (ODN4) & 3906.6 & 3907.7 \\
5'-GCATGTETACGGT-3' (ODN5) & 3888.6 & 3886.7 \\
5'-GCATGAETACGGT-3' (ODN6) & 3897.6 & 3896.9 \\
5'-GCATGA8KTACGGT-3' (ODN7) & 3893.6 & 3893.1 \\
5'-GCATGA3KTACGGT-3' (ODN8) & 3823.5 & 3822.9 \\
5'-GCAAETGTACGGT-3' (ODN19) & 3897.6 & 3896.1 \\
5'-GAETGTACACGGT-3' (ODN21) & 3897.6 & 3896.9 \\
5'-GCATGG3KCACGGT-3' (ODN23) & 3824.5 & 3825.0 \\
\hline
\end{tabular}

Other DNA oligomers were purchased from Sigma Genosys or JBios. 


\section{Diels-Alder reactions catalyzed by DNA metalloenzymes}

The DNA-based hybrid catalyst was prepared in solution by mixing the copper complex and DNA duplex. $40 \mathrm{nmol}$ of the modified oligonucleotide with intrastrand ether linker or intrastrand alkyl linker and the equivalent complementary strand were mixed and freeze dried. Subsequently, $15 \mu \mathrm{L}$ of $2 \mathrm{mM} \mathrm{Cu}\left(\mathrm{NO}_{3}\right)(30 \mathrm{nmol})$ was added to DNA oligomers in $285 \mu \mathrm{L}$ of $20 \mathrm{mM}$ MOPS buffer ( $\mathrm{pH} \mathrm{6.5).} \mathrm{To} \mathrm{conduct} \mathrm{DNA} \mathrm{structure}$ annealing, the solution was kept in $70{ }^{\circ} \mathrm{C}$ in $3 \mathrm{~min}$, cooled to rt, then it was kept at $5^{\circ} \mathrm{C}$ for 1.5 hours. After the annealing sections, substrates were added to the catalyst solution and the reaction mixture was stirred at $5{ }^{\circ} \mathrm{C}$ for 3 days or one day. The product was extracted with $\mathrm{Et}_{2} \mathrm{O}$ and removed the solvent under reduced pressure. The e.e. of the product was determined on a Daicel Chiralcel OD-H column with a solvent mixture of suitable polarity. Hexane: 2-propanol = 95:5 was used with a flow rate of 0.5 $\mathrm{mL} / \mathrm{min}$.

Table S2. Asymmetric Diels-Alder reaction catalyzed by DNA metalloenzymes 
containing $\mathrm{Cu}(\mathrm{II})$ and triethylene glycol (alkyl) linker.<smiles>O=C(/C=C/c1ccccc1)c1ccccn1</smiles>
3a (endo) 3a $(e x o)$

$$
\overbrace{\mathrm{E}}^{\mathrm{O}} \mathrm{NO}_{\mathrm{O}} \mathrm{W}^{\xi_{2}}
$$

\begin{tabular}{|c|c|c|c|c|}
\hline entry ${ }^{a}$ & DNA sequences & $e e(\%)$ & endo/exo & conversion $(\%)$ \\
\hline 1 & $\begin{array}{l}\text { 5'-GCATGAETACGGT-3' (ODN6) } \\
\text { 3'-CGTACTGATGCCA-5' (ODN16) }\end{array}$ & 10 & $12 / 1$ & 97 \\
\hline 2 & $\begin{array}{l}\text { 5'-GCATGAETACGGT-3' (ODN6) } \\
\text { 3'-CGTACTAATGCCA-5' (ODN17) }\end{array}$ & 13 & $12 / 1$ & 95 \\
\hline 3 & $\begin{array}{l}\text { 5'-GCATGAETACGGT-3' (ODN6) } \\
\text { 3'-CGTACTTATGCCA-5' (ODN18) }\end{array}$ & 9 & $13 / 1$ & 99 \\
\hline 4 & $\begin{array}{l}\text { 5'-GCAAETGTACGGT-3' (ODN19) } \\
\text { 3'-CGTTCACATGCCA-5' (ODN20) }\end{array}$ & -97 & $28 / 1$ & 99 \\
\hline 5 & $\begin{array}{l}\text { 5'-GAETGTACACGGT-3' (ODN21) } \\
\text { 3'-CTCACATGTGCCA-5' (ODN22) }\end{array}$ & -68 & $11 / 1$ & 45 \\
\hline $6^{b}$ & $\begin{array}{l}\text { 5'-GCATGG }{ }^{3} \text { KCACGGT-3' (ODN23) } \\
\text { 3'-CGTACCCGTGCCA-5' (ODN10) }\end{array}$ & -59 & $13 / 1$ & 58 \\
\hline
\end{tabular}

Experiments were carried out with $3.3 \mathrm{mM}$ aza-chalcone, $80 \mathrm{mM}$ cyclopentadiene, $0.13 \mathrm{mM}$ DNA, $0.1 \mathrm{mM} \mathrm{Cu}\left(\mathrm{NO}_{3}\right)_{2}$ at $5{ }^{\circ} \mathrm{C}$ in $20 \mathrm{mM}$ MOPS buffer (pH 6.5) for 3 day. The yield and enantioselectivity were determined by chiral HPLC analysis. ${ }^{b}$ Results represent the average value of more than two experiments. The enantioselectivities were reproducible within $\pm 5 \%$. The yields were reproducible within $\pm 10 \%$. 
Table S3. Investigation of metal complexes for DNA metalloenzymes containing triethylene glycol linker.

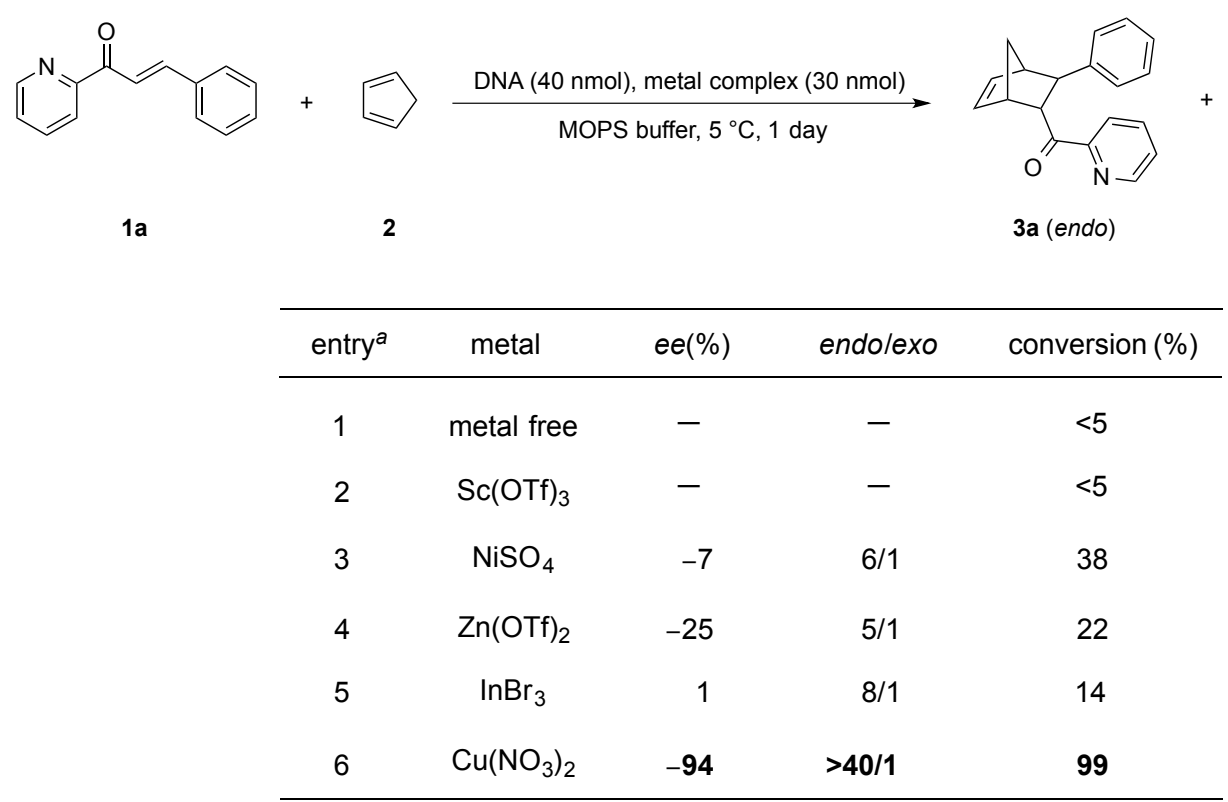

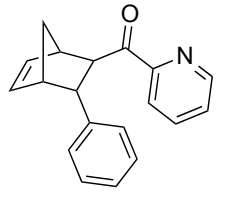

3a (exo)

: Experiments were carried out with $3.3 \mathrm{mM}$ aza-chalcone, $80 \mathrm{mM}$ cyclopentadiene, $0.13 \mathrm{mM}$ DNA (ODN6/ODN15), $0.1 \mathrm{mM}$ metal complex at $5{ }^{\circ} \mathrm{C}$ in $20 \mathrm{mM}$ MOPS buffer ( $\mathrm{pH}$ 6.5) for 3 day. The yield and enantioselectivity were determined by chiral HPLC analysis.

Table S4. Investigation of $\mathrm{Cu}(\mathrm{II})$-cytosine complexes for Diels-Alder reaction.

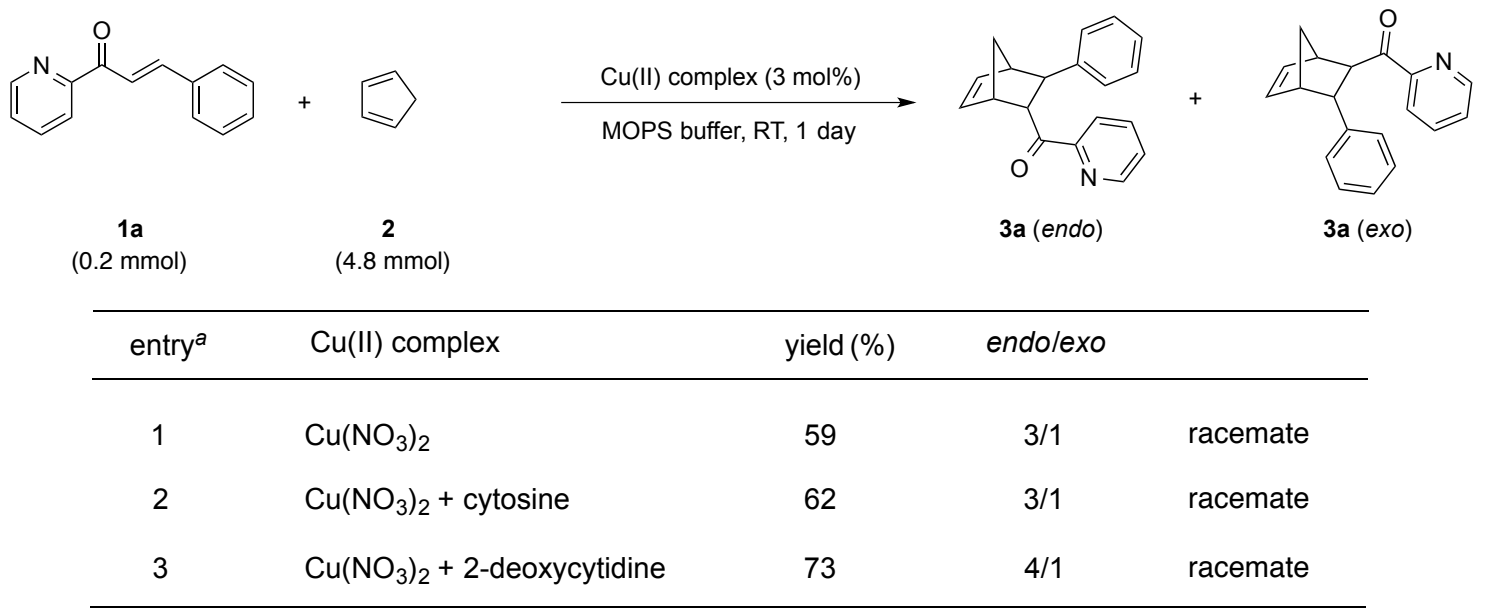


Table S5. Investigation of the amount of Cu(II) complexes for DNA metalloenzymes

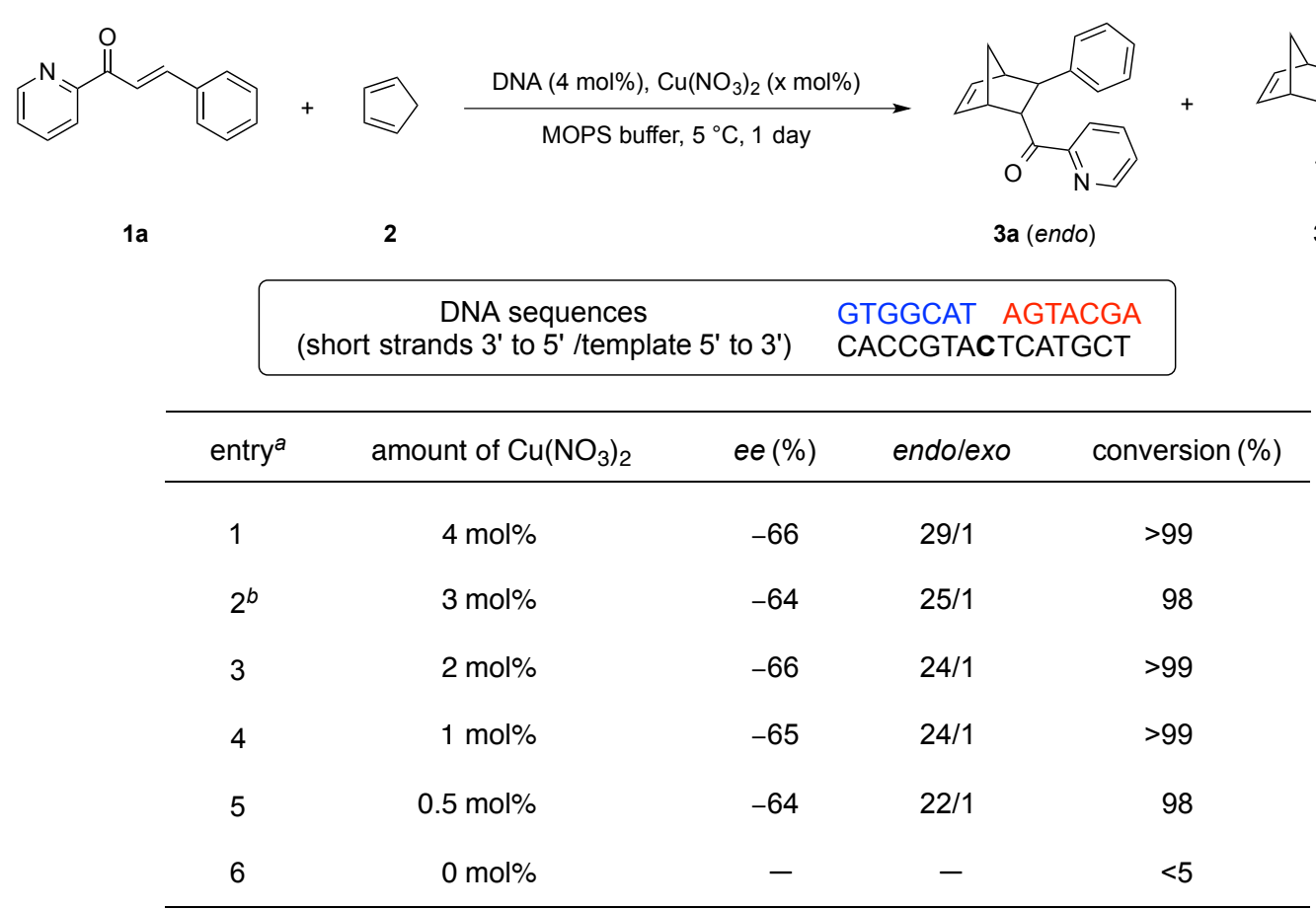

${ }^{a}$ Experiments were carried out using $3.3 \mathrm{mM}$ aza-chalcone, $80 \mathrm{mM}$ cyclopentadiene, $0.13 \mathrm{mM}$ DNA, and $\mathrm{Cu}\left(\mathrm{NO}_{3}\right)_{2}$ at $5{ }^{\circ} \mathrm{C}$ in $20 \mathrm{mM}$ MOPS buffer (pH 6.5) for 1 day. The yields and enantioselectivities were determined by chiral HPLC analysis. ${ }^{b}$ Results represent the average value of more than two experiments. The enantioselectivities were reproducible within $\pm 5 \%$. The yields were reproducible within $\pm 10 \%$. 


\section{Spectroscopy}

CD spectra of oligonucleotide solutions collected in 0.5-nm steps from 320 to $220 \mathrm{~nm}$ were measured using JASCO J-805LST Spectrometer in a 1-cm quartz cuvette. Each spectrum shown is the average of two individual scans.

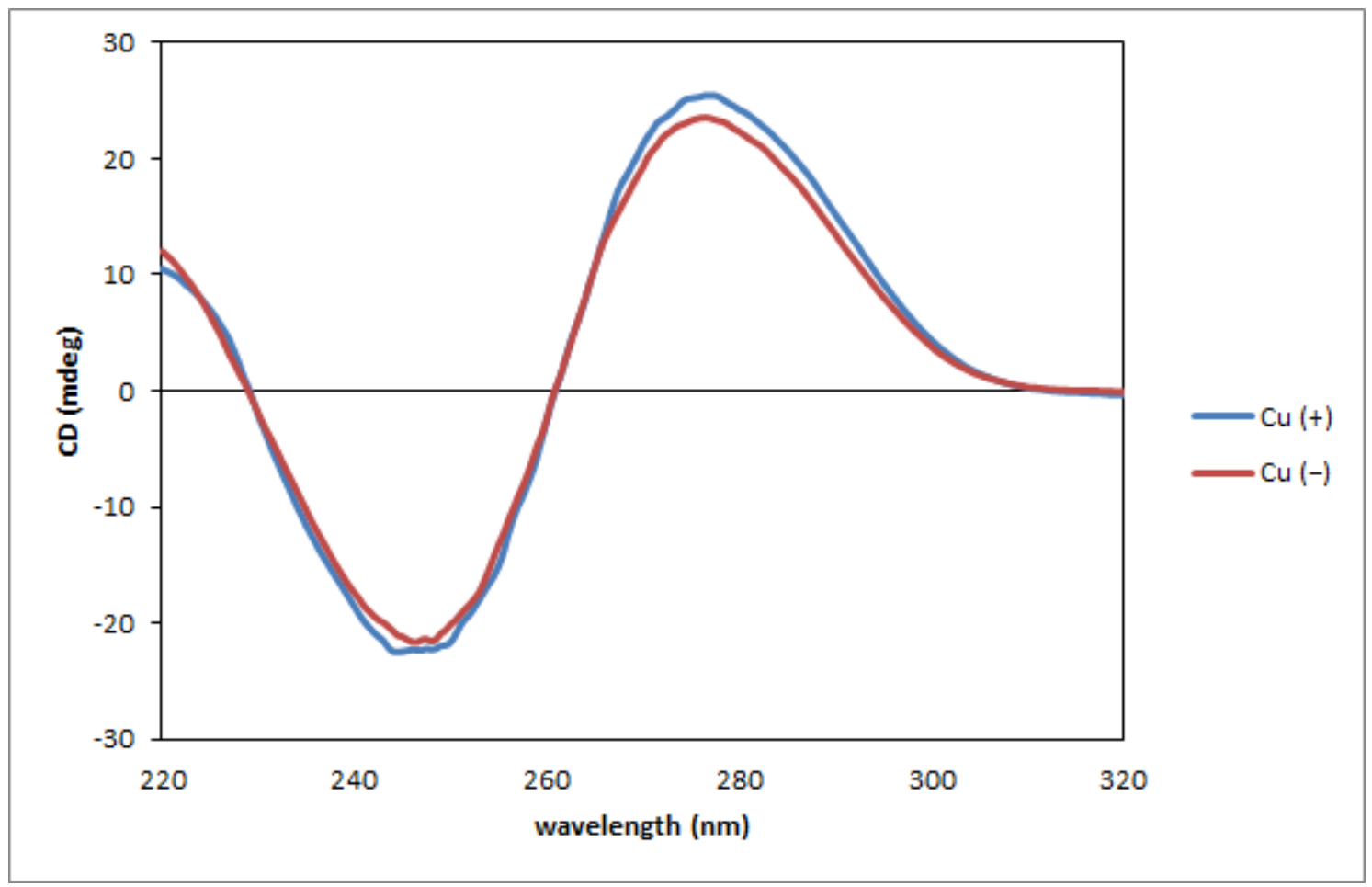

Figure S1. JASCO V-650 UV/VIS spectrophotometer was used to record absorption spectra with a $0.5 \mathrm{~nm}$ resolution. The cuvette temperature was kept at $5{ }^{\circ} \mathrm{C}$ by JASCO PAC-743R. Samples were prepared with $8.3 \mu \mathrm{M}$ of DNA oligomer (ODN6/ODN15) and $8.3 \mu \mathrm{M} \mathrm{Cu}\left(\mathrm{NO}_{3}\right)_{2}$ in $20 \mathrm{mM}$ MOPS buffer (pH 6.5). 


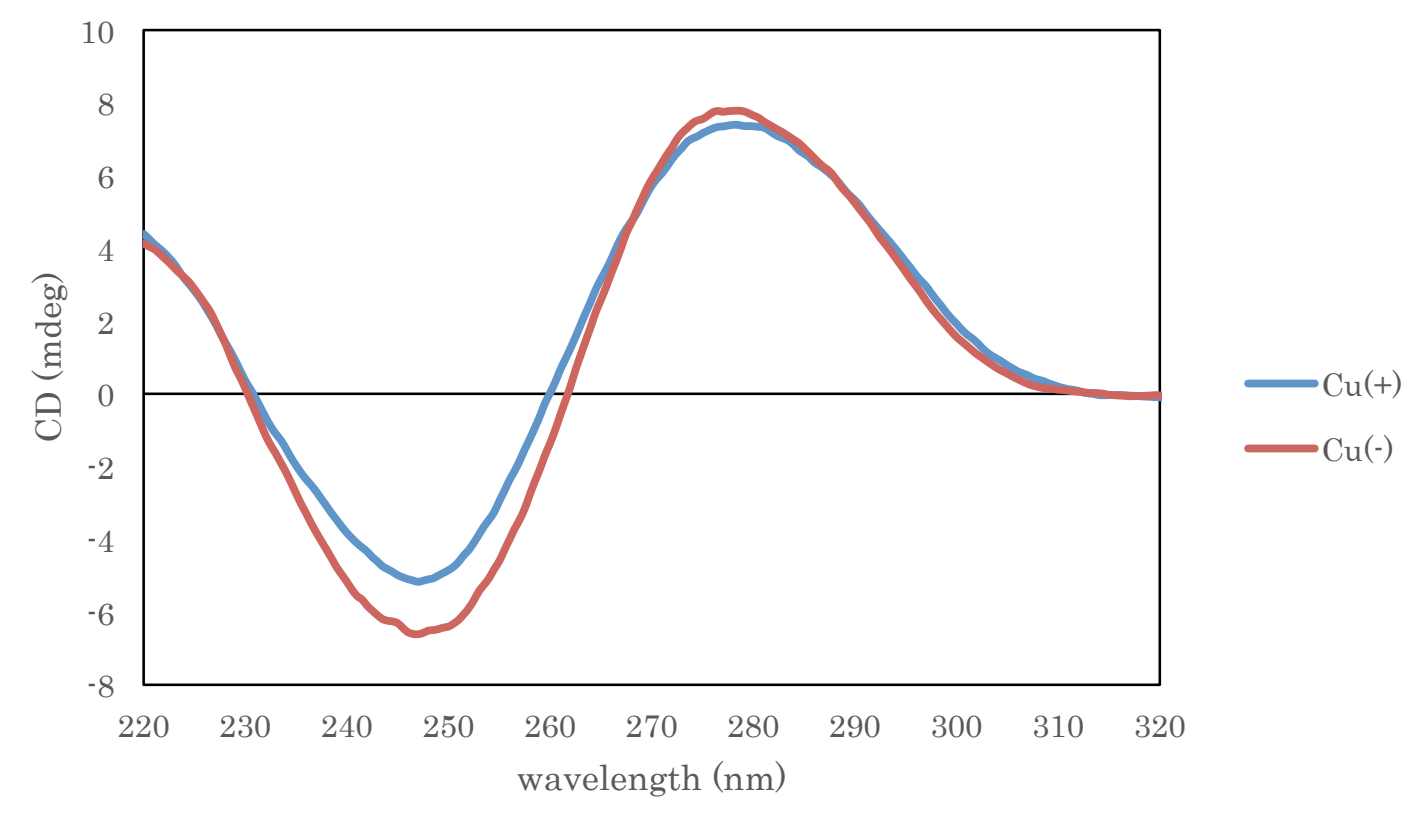

Figure S2. JASCO V-650 UV/VIS spectrophotometer was used to record absorption spectra with a $0.5 \mathrm{~nm}$ resolution. The cuvette temperature was kept at $5{ }^{\circ} \mathrm{C}$ by JASCO PAC-743R. Samples were prepared with $5 \mu \mathrm{M}$ of DNA oligomer (ODN8/ODN15) and $5 \mu \mathrm{M} \mathrm{Cu}\left(\mathrm{NO}_{3}\right)_{2}$ in $20 \mathrm{mM}$ MOPS buffer ( $\left.\mathrm{pH} 6.5\right)$.

\section{UV-melting}

Melting temperature were determined by measuring changes in absorbance at $260 \mathrm{~nm}$ as a function of temperature using a JASCO V-650 UV/VIS spectrophotometer. JASCO PAC-743R equipped with a high performance temperature controller and micro auto eight-cell holder. Absorbance was recorded in the forward and reverse direction at temperatures from 5 to $95{ }^{\circ} \mathrm{C}$ at a rate of $0.5{ }^{\circ} \mathrm{C} / \mathrm{min}$. The melting samples were denatured at $70{ }^{\circ} \mathrm{C}$ for $3 \mathrm{~min}$ and annealed slowly to $\mathrm{RT}$ then stored at $5{ }^{\circ} \mathrm{C}$ until experiments were initiated. All melting samples were prepared in a total volume of 150 $\mu \mathrm{l}$ containing $5 \mu \mathrm{M}$ of each strand oligonucleotide, $5 \mu \mathrm{M} \mathrm{Cu}\left(\mathrm{NO}_{3}\right)_{2}, 20 \mathrm{mM}$ MOPS buffer (pH 6.5) and $100 \mathrm{mM} \mathrm{NaCl}$. 


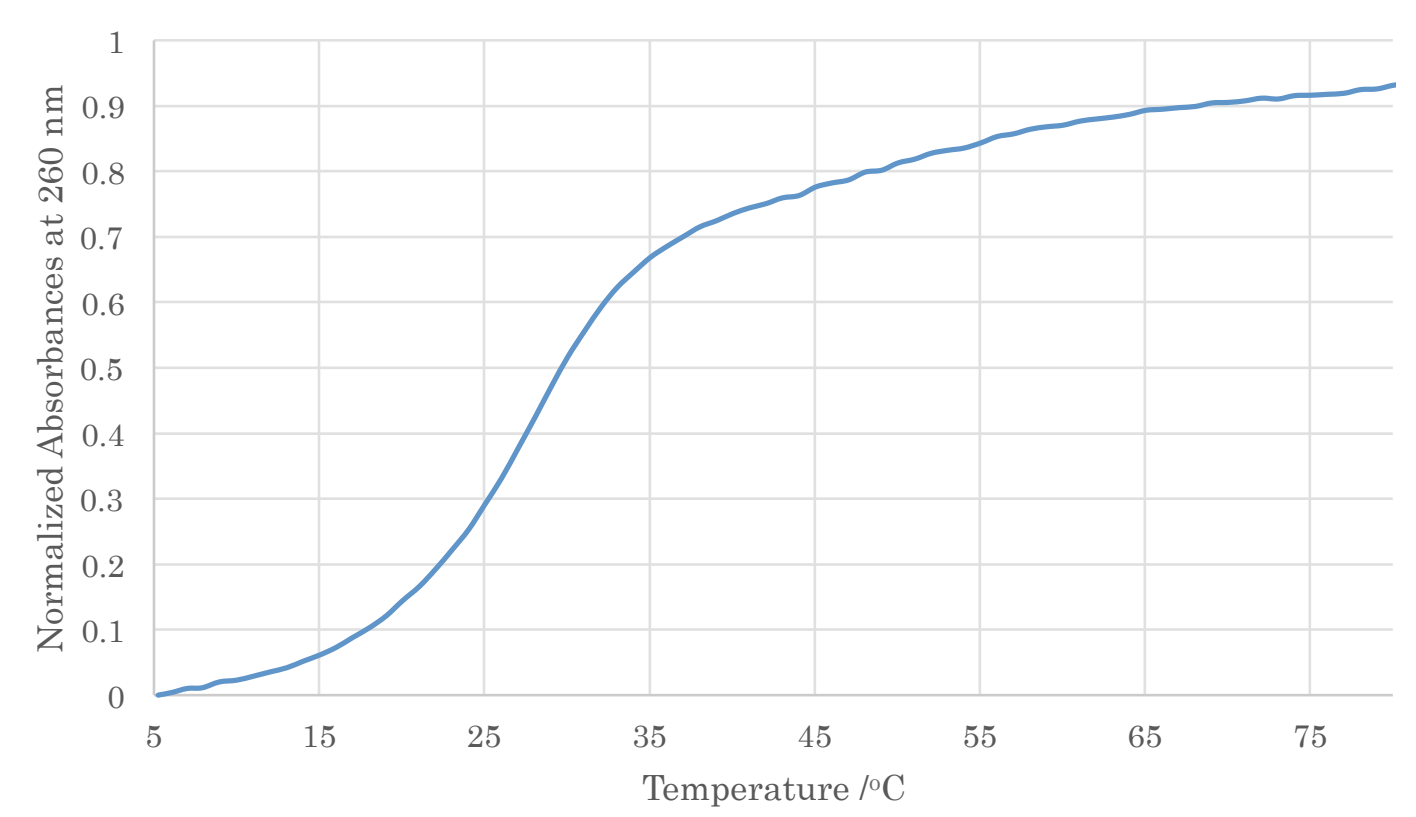

Figure S3. Thermal stability of $\mathrm{Cu}(\mathrm{II})$-DNA-triethylene glycol conjugates, ODN6/ODN15.

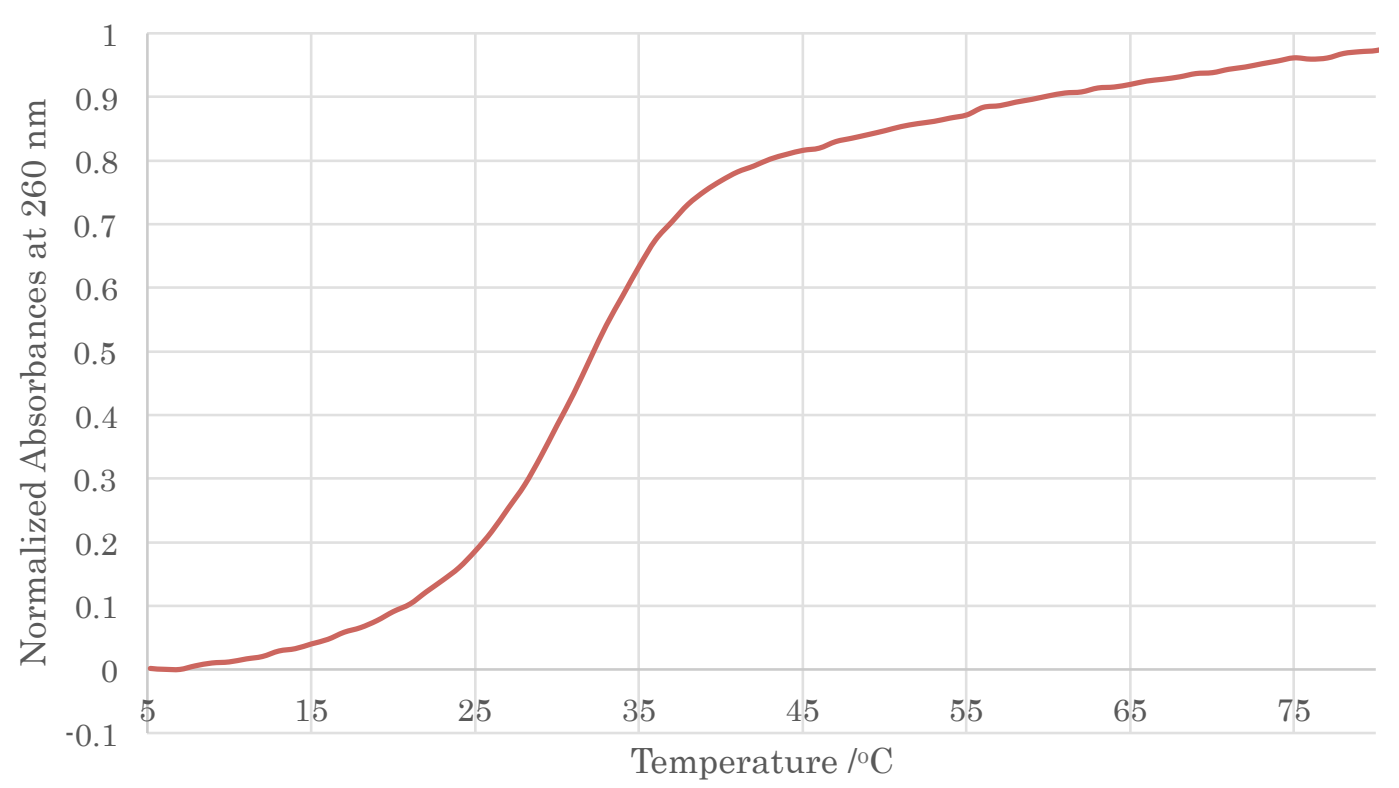

Figure S4. Thermal stability of $\mathrm{Cu}(\mathrm{II})$-DNA-propyl linker conjugates, ODN8/ODN15. 


\section{Molecular Modeling Studies}

Molecular modeling was carried out using the MOE (Molecular Operating Environment) software package. DNA duplexes containing triethylene glycol (propyl or octyl) linker were constructed and minimized with amber force field parameters, a distance-dependent dielectric constant of $\varepsilon=4 \mathrm{r}$ (where, $\mathrm{r}$ is the distance between two atoms) and convergence criteria having an RMS gradient of less than $0.001 \mathrm{kcal} \mathrm{mol}^{-1} \AA$. For energy minimization water molecules were added to produce distance of $10 \AA$ from the solute to droplet sphere boundaries and sodium counter ions were added to neutralize the system.

The MM optimization of the molecular assembly of the aza-chalcone in the asymmetric Diels-Alder reaction and the DNA metalloenzyme was performed by manually docking the most stable conformer of the aza-chalcone into the DNA sequences. Because the carbonyl oxygen and pyridyl nitrogen coordinate to the copper(II) complex, $\mathrm{Cu}$ (II)-N bond and $\mathrm{Cu}(\mathrm{II})-\mathrm{O}$ bond distances were restrained by 2.0-2.5 A (Figure S1). The complex of the lowest-energy conformation of the aza-chalcone and the DNA metalloenzyme was minimized using the Amber force field. During the energy minimization, DNA residues (including backbone) were allowed to move freely. The low-energy conformer of aza-chalcone $\mathbf{1}$ was treated as "frozen atoms". 


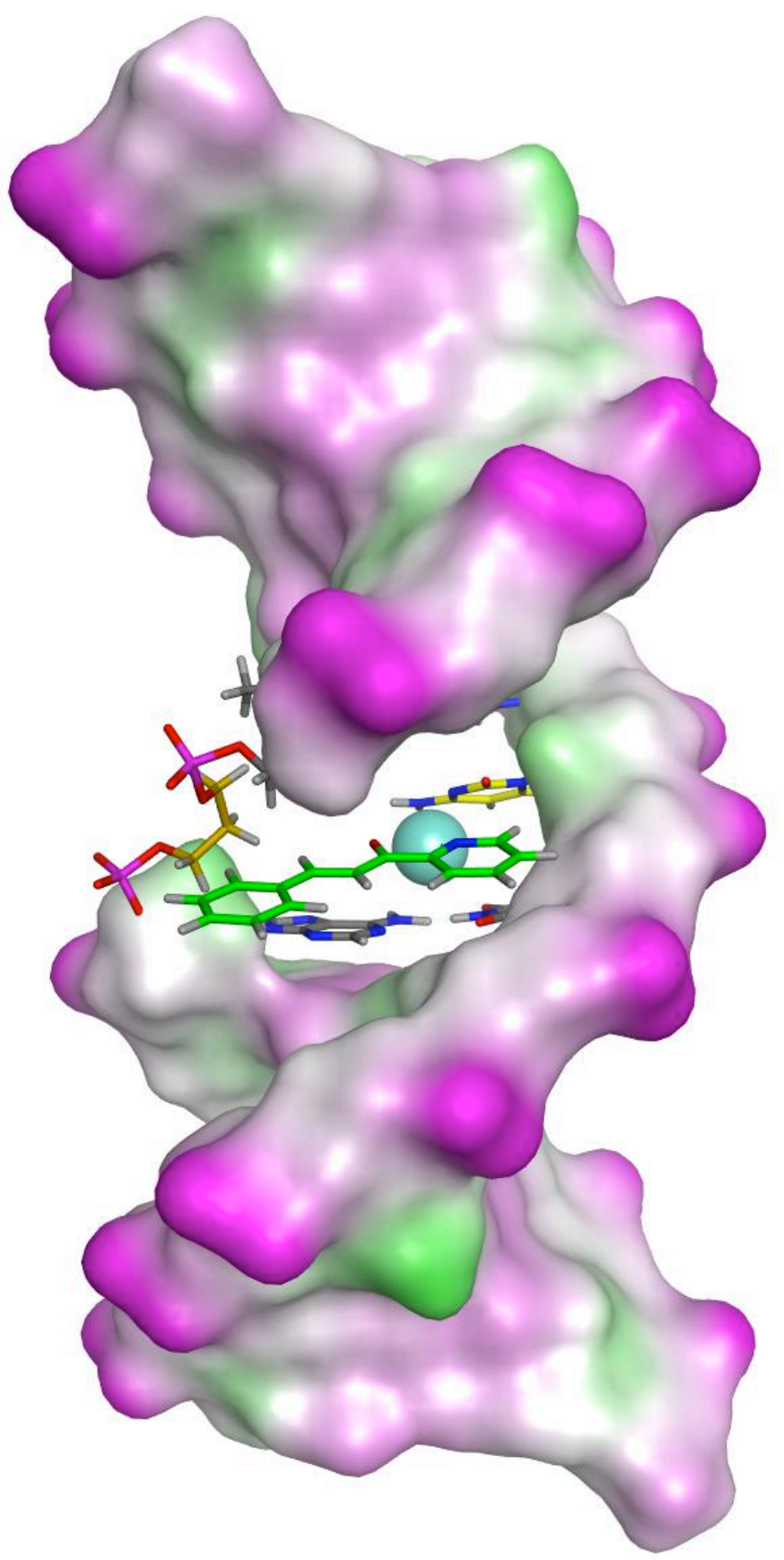

Figure S5. Plausible molecular models of DNA metalloenzymes and aza-chalcone by energy minimization with the Amber force field. DNA metalloenzymes based on ODN8/ODN15 (entry 8 in Table 1). The color of molecular surface represents the lipophilicity (pink, hydrophilic; white, neutral; light green, lipophilic). 
